\title{
The Protein Quality of Oats
}

\author{
By J. G. HEATHCOTE \\ Cereals Research Station, Research Association of British Flour Millers, St Albans
}

(Received 22 February 1950)

The distribution of essential amino-acids within the wheat grain was studied by BartonWright \& Moran (1946) using microbiological methods. By similar methods, McElroy, Clandinin, Lobay \& Pethybridge (1949) recently examined several samples of one variety of oats (Victory), grown on Canadian soils and covering a wide range of nitrogen values, for their content of nine essential amino-acids. From the scattered literature Block \& Bolling (r945) collected data on the content of some twelve amino-acids in oat protein: the values they quote were obtained by a variety of methods, chiefly chemical. However, little is known of the content of the remaining amino-acids, which comprise the major portion of the nitrogen of oat protein. Furthermore, the question of varietal difference does not appear to have been investigated hitherto.

A survey of the distribution of nitrogen within the protein of the oat grain has now been made using chiefly microbiological methods. Samples representative of widely differing varieties of oats have been examined and as many as eighteen amino-acids have been determined together with amide nitrogen. The results have accounted for over $85 \%$ of the total nitrogen of the groat or kernel. In view of the fact that the nonprotein nitrogen of the groat may well account for some $6 \%$ of the total nitrogen (see, for example, Teller, 1932), this figure of $85 \%$ must represent almost the whole of the protein. Of the more common amino-acids only hydroxyproline and hydroxylysine (Van Slyke, Hiller, Dillon \& MacFadyen, 1938; Heathcote, 1948) have not been determined.

Some amino-acid analyses were also made on the husk.

\section{MATERIALS AND METHODS}

Choice of the samples of groats

The samples were chosen because of differences in type, pedigree, nitrogen content, fat content, ash content, physical characteristics, and season; they are believed to be representative of the different varieties of British oats grown in widely contrasting soils and seasons. The particular varieties examined, together with their location, season and analysis (data supplied by $\mathrm{Dr}$ J. B. Hutchinson and Mr H. F. Martin) are given in Table I.

The years 1946 and 1947 provided a most exceptional contrast in seasons. The former season was wet with little sunshine throughout the growing, ripening and harvesting periods. The season of 1947 , on the other hand, was extremely dry and sunny throughout almost the whole of the corresponding periods. 
Table $\mathrm{I}$. The percentages of nitrogen, oil, ash and kernel in different varieties of oats grown in different soil zones in 1946 and 1947

(The different varieties are grouped in pairs to bring out some of the differences for which the varieties were chosen)

\begin{tabular}{|c|c|c|c|c|c|c|c|}
\hline $\begin{array}{l}\text { Characteristics } \\
\text { compared }\end{array}$ & Variety & Soil zone & Season & $\begin{array}{l}\text { Nitrogen } \\
(\%)\end{array}$ & $\begin{array}{l}\mathrm{Oil} \\
(\%)\end{array}$ & $\begin{array}{l}\text { Ash } \\
(\%)\end{array}$ & $\begin{array}{c}\text { Kernel } \\
\text { content } \\
\text { of oats } \\
(\%)\end{array}$ \\
\hline $\begin{array}{l}\text { Low oil } \\
\text { High oil }\end{array}$ & $\begin{array}{l}\text { Garton's Superb } \\
\text { Gordon }\end{array}$ & $\begin{array}{l}\text { Cheshire } \\
\text { Scotland }\end{array}$ & $\begin{array}{l}1947 \\
1946\end{array}$ & $\begin{array}{l}2 \cdot 28 \\
2 \cdot 00\end{array}$ & $\begin{array}{r}4 \cdot 9 \\
10 \cdot 5\end{array}$ & $\begin{array}{l}2 \cdot 22 \\
2 \cdot 03\end{array}$ & $\overline{-}$ \\
\hline $\begin{array}{l}\text { Low kernel } \\
\text { High kernel }\end{array}$ & $\begin{array}{l}\text { Onward } \\
\text { Grey Winter }\end{array}$ & $\begin{array}{l}\text { Cheshire } \\
\text { Somerset }\end{array}$ & $\begin{array}{l}1947 \\
1946\end{array}$ & $\begin{array}{l}2 \cdot 17 \\
2 \cdot 05\end{array}$ & $\begin{array}{l}5 \cdot 4 \\
9 \cdot 6\end{array}$ & $\begin{array}{l}2 \cdot 16 \\
2 \cdot 00\end{array}$ & $\begin{array}{l}67 \cdot 6 \\
79 \cdot 7\end{array}$ \\
\hline $\begin{array}{l}\text { Low nitrogent } \\
\text { High nitrogen } \$\end{array}$ & $\begin{array}{l}\text { S I } 47 \\
\text { Victory }\end{array}$ & $\begin{array}{l}\text { Hertfordshire } \\
\text { St Albans }\end{array}$ & $\begin{array}{l}1946 \\
1947\end{array}$ & $\begin{array}{l}1 \cdot 76 \\
3 \cdot 41\end{array}$ & $\begin{array}{l}7 \cdot 6 \\
5 \cdot 4\end{array}$ & $\begin{array}{l}1 \cdot 89 \\
2 \cdot 54\end{array}$ & $\overline{-}$ \\
\hline $\begin{array}{l}\text { High nitrogen } \\
\text { High ash }\end{array}$ & $\begin{array}{l}S_{172} \\
\text { No. } 202 \S\end{array}$ & $\begin{array}{l}\text { Sprowston } \\
\text { Cheshire }\end{array}$ & $\begin{array}{l}1946 \\
1947\end{array}$ & $\begin{array}{l}3 \cdot 00 \\
2 \cdot 48\end{array}$ & $\begin{array}{l}8 \cdot 1 \\
6 \cdot 6\end{array}$ & $\begin{array}{l}2 \cdot 35 \\
2 \cdot 51\end{array}$ & - \\
\hline $\begin{array}{l}\text { Low ash } \\
\text { Iow ash }\end{array}$ & $\begin{array}{l}\text { Onward } \\
\text { Onward }\end{array}$ & $\begin{array}{l}\text { Shropshire } \\
\text { Scotland }\end{array}$ & $\begin{array}{l}1946 \\
1946\end{array}$ & $\begin{array}{l}2 \cdot 05 \\
2 \cdot 15\end{array}$ & $\begin{array}{l}5 \cdot 8 \\
6 \cdot 4\end{array}$ & $\begin{array}{l}1 \cdot 91 \\
1 \cdot 87\end{array}$ & - \\
\hline $\begin{array}{l}\text { Low nitrogen|| } \\
\text { High nitrogen|| }\end{array}$ & $\begin{array}{l}\text { Onward } \\
\text { Yielder }\end{array}$ & $\begin{array}{l}\text { Ayrshire } \\
\text { Wiltshire }\end{array}$ & $\begin{array}{l}1946 \\
1946\end{array}$ & $\begin{array}{l}I \cdot 86 \\
2 \cdot 8 I\end{array}$ & $\begin{array}{l}6 \cdot 1 \\
6 \cdot 2\end{array}$ & $\begin{array}{l}2 \cdot 05 \\
2 \cdot 10\end{array}$ & - \\
\hline I.ow nitrogen & $\mathrm{S}_{147}$ & Cheshire & 1946 & $2 \cdot 29$ & $6 \cdot 9$ & $2 \cdot 23$ & 一 \\
\hline High nitrogen & $\begin{array}{l}\text { Victory } \\
\text { Ayr Bounty }\end{array}$ & $\begin{array}{l}\text { Cambridge } \\
\text { Scotland }\end{array}$ & $\begin{array}{l}1946 \\
1946\end{array}$ & $\begin{array}{l}2 \cdot 93 \\
2 \cdot 63\end{array}$ & $\begin{array}{l}5 \cdot 4 \\
8 \cdot 0\end{array}$ & $\begin{array}{l}2 \cdot 15 \\
2 \cdot 29\end{array}$ & - \\
\hline \multicolumn{8}{|c|}{$\begin{array}{l}\text { These figures refer to the moisture-free kernel. } \\
\dagger \text { With low ash content. } \\
\pm \text { With high ash content. } \\
\text { \$ This sample was supplied privately by Gartons Ltd., Warrington. } \\
\text { \|! With medium ash content. }\end{array}$} \\
\hline
\end{tabular}

\section{Preparation of the groat samples}

'The oats were carefully hulled by hand to ensure that the germ was not excluded. The groats so prepared were then finely ground in a Christy-Norris mill (Christy and Norris Ltd., Chelmsford) and the resultant wholemeal samples were used in the preparation of hydrolysates for microbiological assay.

\section{Preparation of hydrolysates for assay}

'Two main types of hydrolysates were prepared.

\section{Hydrolysates for assays other than that of tryptophan}

Representative subsamples $(5 \mathrm{~g}$.) of each wholemeal sample of groats were hydrolysed for $4 \frac{1}{2}-6 \mathrm{hr}$. in an autoclave at $15 \mathrm{lb}$. pressure with $25 \mathrm{ml} .2 \cdot 5 \mathrm{~N}-\mathrm{HCl}$. To the cooled hydrolysate $2 \mathrm{ml} .2 \cdot 5 \mathrm{M}$-sodium-acetate solution were added and the $\mathrm{pH}$ was adjusted to 4.5 with sodium hydroxide. Most of the coloured humin which precipitates at this $\mathrm{pH}$ flocculated on standing, and the mixture was then filtered into a $500 \mathrm{ml}$. flask. The filtrate, together with the washings of the precipitate, was neutralized to $\mathrm{pH} 6.8$ and made up to $500 \mathrm{ml}$. This stock solution was covered with toluene and stored in the refrigerator, portions being appropriately diluted for analysis of the individual aminoacids. 
Hydrolysates for the assay of tryptophan

Subsamples ( $1 \mathrm{~g}$. of each) were hydrolysed with aqueous baryta ( $7 \cdot 7 \mathrm{~g}$. dissolved in Io $\mathrm{ml}$. water) until the liberated tryptophan was completely racemized (8 hr.). The hydrolysate was next diluted and freed from baryta as described by Greene \& Black (1944). After successive extractions with diethyl ether and toluene, to remove any indole or anthranilic acid that might be present in the hydrolysate and which might be stimulatory to Lactobacillus arabinosus, the $\mathrm{pH}$ of the hydrolysate was taken to $6 \cdot 8$. The solution was finally diluted to $500 \mathrm{ml}$. and stored under toluene in the refrigerator.

\section{Individual methods of assay}

Alanine. Many organisms were used in attempts to assay this amino-acid. The use of Streptococcus faecalis was proposed by Brand, Saidel, Goldwater, Kassell \& Ryan (1945), but no details appear to have been published and the organism has failed to give a satisfactory assay on all media that have been tested in this laboratory. Sauberlich \& Baumann (I949) recently proposed the use of Leuconostoc citrovorum (American Type Culture Collection no. 808I) and this organism was used during the present assays. The medium was similar to that proposed by Henderson \& Snell (1948), but with minor modifications, chiefly in increased vitamin content. To this medium a small amount of liver extract was added.

Arginine and threonine. These acids were assayed by means of Strep. faecalis using the basal medium of Stokes, Gunness, Dwyer \& Caswell (1945) with the modifications proposed by Barton-Wright (1946).

Glutamic acid was determined by the method of Dunn, Camien, Shankman \& Block (1947), using Strep. faecalis.

Cystine, methionine and tyrosine. Leuconostoc mesenteroides $\mathrm{P} 60$ was used. The medium was sometimes the uniform medium described for the alanine assays and sometimes essentially that of Lyman, Moseley, Wood \& Hale (1946) with minor modifications, chiefly in the vitamin and mineral concentrations.

Serine. A new assay has been proposed (Heathcote, unpublished data) for this amino-acid and will be described in detail elsewhere.

Tryptophan, leucine and valine. The modified methods described by Barton-Wright (1946) were used for these amino-acids.

Aspartic acid, glycine, histidine, isoleucine, lysine, phenylalanine and proline. 'The uniform medium used for the alanine assays was adopted for the estimation of these amino-acids; the organism was $L$. mesenteroides $\mathbf{P} 60$.

\section{Some factors affecting the accuracy of the microbiological estimations}

Bacterial growth was measured after incubation at $37^{\circ}$ for $7^{2} \mathrm{hr}$. by titrating the acid produced with sodium-hydroxide solution which varied in strength from 0.02 to $0.1 \mathrm{~N}$. In some assays more than one organism was used for the same amino-acid in order to cross-check the result. Snell (I945) has pointed out that if two, or more, organisms differing in other nutritive requirements yield the same assay value on one sample, the probability that the assay value is correct is greatly increased since it is improbable 
that such organisms would respond to interfering materials in exactly the same manner and to the same extent. In other assays, values have been checked against those obtained by accepted chemical methods, e.g. Millon-Nasse (tyrosine) or SakaguchiWeber (arginine) (Block \& Bolling, 1945).

The reproducibility of the mean value obtained for the content of a particular aminoacid in a protein hydrolysate depends in every method on the number of individual replicate determinations carried out. Most of the values reported here are the average of two such determinations; but often three, or more, determinations were made.

Aspartic and glutamic acids. Prolonged boiling with strong acids is known to cause partial conversion of the L-forms of these amino-acids to their respective racemic mixtures. Since the microbiological methods described above for the determination of aspartic acid and glutamic acid estimate only the L-form, any racemization that might occur would lead to low results. An attempt to determine by the method of Dunn et al. (1947) the amount of racemization occurring with glutamic acid was unsuccessful. According to this method, Lactobacillus lycopersici (brevis) is stated to produce almost identical growth responses for the $\mathrm{L}(+), \mathrm{D}(-)$ and the DL-forms of glutamic acid. Assays carried out using this organism, together with assays employing Strep. faecalis which determines only the $\mathrm{L}(+)$-form, should lead to an evaluation of the total glutamic acid present in the hydrolysate. It was found, however, that Lact. lycopersici produced growth responses with additions of DL-glutamic acid that were lower than those produced by similar additions of the $L(+)$-form. The method obviously needed further investigation, which was not undertaken during the present study.

However, it was not possible to detect any decrease in the content of L-glutamic acid when the time of hydrolysis with $2 \cdot 5 \mathrm{~N}-\mathrm{HCl}$ was raised from $4 \frac{1}{2}$ to $6 \mathrm{hr}$. This fact, together with certain results obtained with the proteins, zein and casein, indicated that little racemization had taken place under the comparatively mild experimental conditions used.

Serine. According to Martin \& Synge (1945) strong acid hydrolysis for 24 hr. may cause up to 10 \% loss of serine. Destruction of serine is unlikely to have occurred under the present experimental conditions, and certainly there was no apparent reduction in the serine results when the time of hydrolysis was increased from $4 \frac{1}{2}$ to $6 \mathrm{hr}$.

Arginine. Arginine is reported to be slowly destroyed when plant proteins are hydrolysed by prolonged boiling with strong acids in the presence of carbohydrates (Tristram, 1939). Destruction, however, did not appear to take place to any appreciable extent under the conditions of hydrolysis employed during the present experiments, namely $2 \cdot 5 \mathrm{~N}-\mathrm{HCl}$ for $4 \frac{1}{2}-6 \mathrm{hr}$.

Cystine. Individual assays of this particular amino-acid are variable (cf. Heathcote, 1949). Provided, however, that sufficient replicate determinations are carried out on a particular sample, the mean value will be a fairly reliable estimate of the true cystine content. The mean result obtained in this way was the same as that obtained by Block \& Bolling (1945) by chemical methods (Table 2). 


\section{The determination of amide nitrogen}

Suitable portions of the neutralized ( $\mathrm{pH} 6.8$ ) hydrolysates (for assays other than tryptophan) were washed into the distillation flask of the Pregl micro-Kjeldahl apparatus and treated with alkaline-borate buffer. The buffer and general technique used were those described by Rees (1946). The ammonia was distilled into $0.01 \mathrm{~N}-\mathrm{HCl}$ and the excess acid titrated with $0.01 \mathrm{~N}-\mathrm{NaOH}$. Partial destruction of certain amino-acids, such as serine, is known to occur on prolonged boiling with strong acids and this may give rise to additional ammonia (Martin \& Synge, 1945). However, in the experiments described in this paper, the comparatively mild conditions employed in the preparation of the hydrolysates ensured that such destruction was negligible. The method was found to give highly reproducible results and the figure for amide nitrogen is probably the most accurate determination of the whole analysis apart from that of total nitrogen.

\section{Nitrogen distribution within the oat husk}

The nitrogen content of oat husk is low. Berry (1920) recorded a range of values from 0.15 to $0.5 \%$. The value $(0.6 \%)$ quoted by Morrison (1947) is outside this range but is unlikely to have been derived from analysis of pure husk. Richardson (1886) in an analysis of I IO samples reported an average figure of $0.4 \%$. Little is known of the distribution of this nitrogen within the husk, but it is generally believed that the proportion of non-protein nitrogen is much greater in the husk than in the groat.

A few amino-acid analyses were carried out on a sample of oat husk corresponding to one of the samples of groats (variety $\mathrm{S}_{147}$ ) that had been analysed in detail as described in the previous section.

\section{Preparation of the husks for analysis}

A sample (about $4 \mathrm{~g}$.) of hand-separated husk was carefully examined to ensure that it was free from germ and was then ground in a Christy-Norris mill. Milling resulted in the formation of two separate fractions, one consisting of fine particles and comprising about one-third of the whole; the other, and comparatively coarser, fraction accounting for two-thirds of the weight of the husk. The nitrogen content of the fine fraction was $0.41 \%$ and of the coarse fraction $0.11 \%$.

\section{Methods of analysis}

The methods employed for the analysis of the individual amino-acids quoted below were essentially those reported earlier in this paper. The technique, however, was refined to permit of the assay of much smaller amounts of material than had been used previously. It is hoped to make the details of this refinement the subject of a separate communication. The nitrogen determinations were carried out by the usual microKjeldahl method.

\section{RESULTS AND DISCUSSION}

\section{The nitrogen distribution and amino-acid content of groats}

As stated in the previous section, the oat samples were chosen from widely differing types. This method of selection was adopted in order to expose any gross differences in protein composition between these types. However, the differences in protein com- 
position between the samples examined, as revealed by the data, are comparatively small. Consequently, any varietal or environmental effects must likewise be small and could only be assessed at a high level of significance by the statistical examination of data covering a larger number of samples within each variety. On the whole, any such differences, if they exist, are of a comparatively minor nature.

Table 2 gives the weights of the individual protein constituents that are set free on hydrolysis as percentages of the weight of the dry groat. Also given in the same table is the amino-acid composition of oat protein expressed on the assumption that it contains $16 \%$ nitrogen*: this mode of presentation of results may not be ideal, but since many of the data in the literature on the proteins of foods have been worked out on the assumption of a common ( $16 \%$ ) nitrogen basis, the figures are included for comparison.

In Table 2 the percentage of the total nitrogen contributed by each individual fraction of the protein is also shown, and the values are compared with a few figures (available for Victory oats only) provided by other workers. The figure for total nitrogen in these calculations includes both protein and non-protein nitrogen. The exact figure for the latter is not known, but according to Teller (r932) it averages about $6.3 \%$ of the total nitrogen. Since more than $85 \%$ of the total nitrogen is accounted for in Table 2, this means that almost the whole of the protein has been identified in its constituents.

\section{The protein-conversion factor for oats}

The percentage of protein in most foods is obtained by determining the nitrogen according to the Kjeldahl method and multiplying this value by a conversion factor. An early factor for this purpose was 6.33 , based on the assumption that protein of unknown nature had an average of $15.8 \%$ nitrogen. Following this the round number of $16 \%$ nitrogen was taken as representative and the factor 6.25 was thus obtained.

Teller ( 1896 ), basing his calculations on the average amount of nitrogen found in the proteins of wheat by Osborne $\&$ Voorhees ( 1893 ), selected the factor 5.7 for this grain. This was not regarded as exact but was taken as a convenient number close to the truth. The same factor was likewise considered close enough for rye and barley, since a limited number of preparations and analyses showed that the proteins of these grains agreed closely in composition and properties with those of wheat.

Jones (1926), using a factor of 5.7 for wheat flour (endosperm) and taking account of Osborne's (1924) work on the composition of the proteins of the embryo and of his own work (Jones \& Gersdorff, 1925) on the proteins of bran, concluded that a conversion factor of 5.83 would give the protein content of whole wheat more closely than the factor 5.7 . Later this same author (Jones, 193I) stated that 'the factor 5.83 , which has been calculated for wheat, can therefore be used for rye, barley and oats'. This conclusion was based upon the following considerations. The proteins of these cereals were found to consist chiefly of an alcohol-soluble protein, prolamin, and a glutelin. Several investigators have shown that the nitrogen content of these proteins agrees closely with that of gliadin and glutenin, the corresponding proteins of wheat. Like

\footnotetext{
- See, however, the following section on the protein-conversion factor for oats.
} 


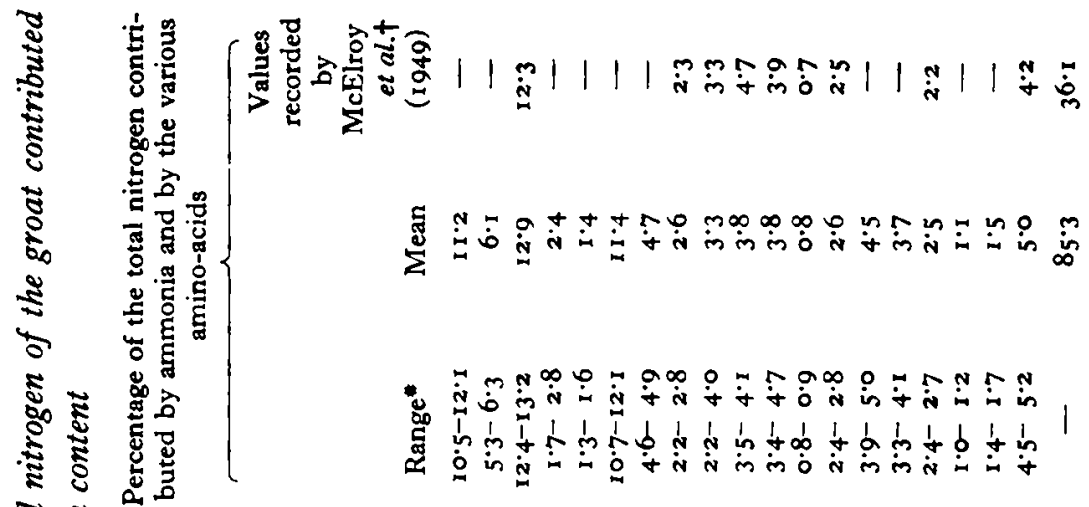

จุั

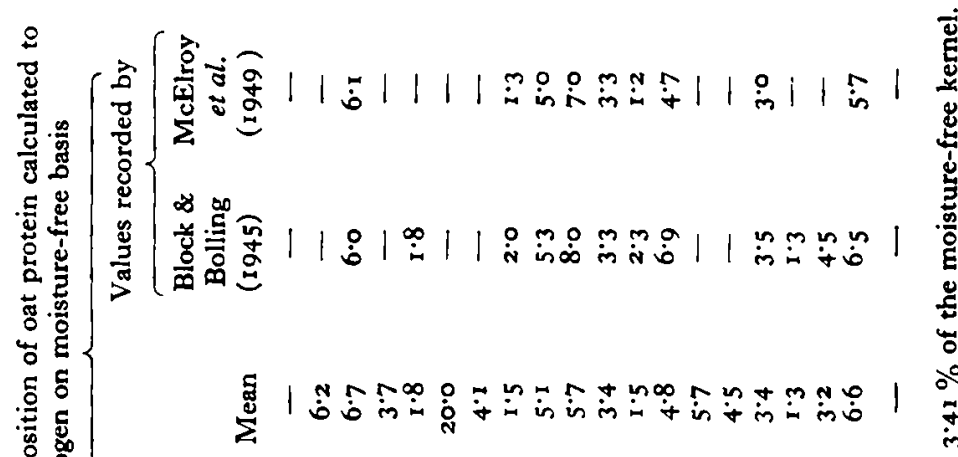

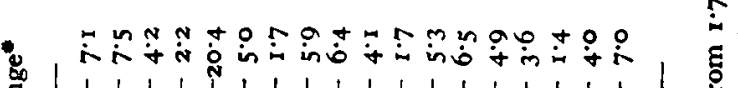

हूँ

范

蛋

2.:

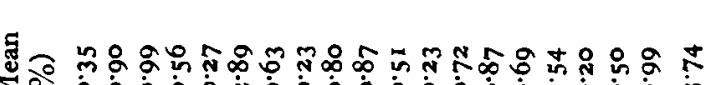

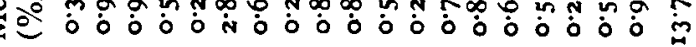

क.

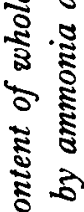

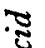

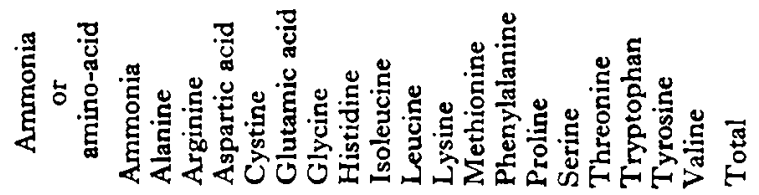

i

茎

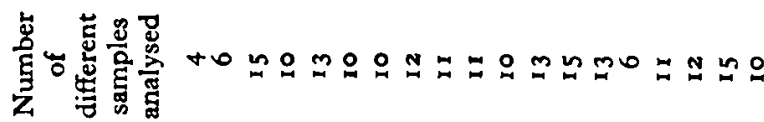


wheat, these cereals contain other proteins but their quantity is proportionately so small that they need not be considered in calculating the conversion factor.

Teller (I932) pointed out, however, that this proposed factor is based on proteins only and that, since the total nitrogen found in the usual analysis of grains includes both protein and non-protein nitrogen, the presence of the latter should not be overlooked in a search for greater accuracy. Teller's conclusion, based upon experimental determinations of the protein and non-protein nitrogen in seeds and in milled products, was that the factor 5.83 was not as accurate as that, 5.7 , he had proposed originally. Teller did not, however, advocate the use of factors that take into account the content of non-protein nitrogen in cereals, owing to the variable amount and complexity of the non-protein nitrogenous constituents.

The analyses of the oat grain collected in Table 2 probably represent the most complete analysis of the protein of any cereal. It is therefore of interest to calculate the protein conversion factor from these new data. From Table 2 it will be seen that, on average, $13.74 \%$ of the dry weight of the groat is composed of ammonia or amino-acids. Since these constituents are present in the protein as amide or amino-acid residues, their combined weight in the protein structure is only $11.35 \mathrm{~g} . / 100 \mathrm{~g}$. groats. The nitrogen contributed collectively by these $11 \cdot 35 \mathrm{~g}$. residues is $2 \cdot 10 \mathrm{~g}$. Hence I g. nitrogen corresponds to 5.40 g. residues, i.e. presumed protein structure.

This conversion factor of 5.40 corresponds to a nitrogen content of $18.5 \%$ in the protein of the oat grain. If the question of non-protein nitrogen were to be considered the factor would be even further reduced. It seems unlikely, when allowance is made for the presence of non-protein nitrogen, that the small amount of protein nitrogen unaccounted for, in terms of amino-acid residues, would alter the factor 5.40 markedly.

It should, however, be pointed out that, owing to the relatively large proportion by weight of glutamyl residues in the protein molecule and to the low nitrogen content of glutamic acid, any racemization which might occur would necessitate some slight raising of this factor. Direct proof of the absence of racemization is lacking but, as already mentioned, indirect evidence supports the view that racemization must have been of a low order in the hydrolysates used in the present work.

\section{Nitrogen distribution within the oat husk}

Table 3 expresses the content, as percentage of total nitrogen, of each of four aminoacids in the husk and its milled fractions. Despite the considerable difference in the total nitrogen content between the coarse and the fine fractions of the husk, the percentages of the total nitrogen contributed by the individual amino-acids appeared to be much the same in the two fractions. The proline content of the fine husk fraction was not obtained but, by extrapolating the value obtained for this amino-acid on the coarse fraction from the nitrogen ratio, it would seem that the proline content of whole husk is higher than the glutamic-acid content. This is the reverse of what obtains in the kernel.

- In the calculation of the residues the chief assumptions made are ( $I$ ) that the non-peptide, carboxyl group of aspartic acid or glutamic acid is present as the amide grouping, ( 2 ) that the $\delta$-guanido group of arginine and the $\epsilon$-amino group of lysine remain free and ( 3 ) that histidine combines in the protein structure as if it were a monoamino-monocarboxylic acid. 
Table 3. A comparison of the partial percentage distribution of nitrogen within the kernel, husk and milled fractions of the husk, all derived from the same sample of oats (variety $\mathrm{S}_{147}$ )

Nitrogen fraction
Total nitrogen
Glutamic-acid nitrogen
Histidine nitrogen
Lysine nitrogen
Proline nitrogen

\begin{tabular}{|c|c|c|}
\hline \multicolumn{2}{|c|}{ Husk fraction } & \multirow[b]{2}{*}{ Whole husk } \\
\hline Fine & Coarse & \\
\hline 0.41 & 0.11 & 0.21 \\
\hline
\end{tabular}

Nitrogen as percentage of total nitrogen

- All values expressed on a moisture-free basis.

$\begin{array}{rllr}2.3 & 2 \cdot 0 & 2.2 & 11 \cdot 6 \\ 0.7 & 1 \cdot 0 & 0.9 & 2.7 \\ 2.3 & 2 \cdot 0 & 2 \cdot 1 & 3.4 \\ - & 3.6 & 3.8+ & 4.9\end{array}$

+ Extrapolated value.

A comparison between the kernel and the husk derived from the same sample of oats (Table 3), reveals a substantial diminution in the respective percentages of nitrogen of all four amino-acids in the total nitrogen of the husk. This reduction was most marked with glutamic acid and histidine and was least with proline.

\section{SUMMARY}

1. An extensive survey of the nitrogen distribution within the oat grain has been made using chiefly microbiological methods. No gross varietal differences in the composition of oat protein have been detected.

2. Over $85 \%$ of the total nitrogen of the oat grain can be accounted for in terms of amide- and amino-acid-nitrogen. The significance of this finding with reference to the nitrogen conversion factor for oat protein is discussed.

3. The content of glutamic acid, histidine, lysine and proline in the protein of the husk was determined. The values were lower than those for the protein of the kernel.

I am indebted to my colleague, Dr J. B. Hutchinson, for selecting, and providing me with, the samples of oats and for help on many technical points. The work is part of a programme of research being carried out in these laboratories for the Oatmeal Millers of England and Scotland.

\section{REFERENCES}

Barton-Wright, E. C. (1946). Analyst, 71, 267.

Barton-Wright, E. C. \& Moran, T. (1946). Analyst, 71, 278.

Berry, R. A. (1920). F. agric. Sci. 10, 359.

Block, R. J. \& Bolling, D. (1945). The Amino-Acid Composition of Proteins and Foods, p. 305. Springfield, Illinois: C. G. Thomas.

Brand, E., Saidel, L. J., Goldwater, W. H., Kassell, B. \& Ryan, F. J. (1 945). 7. Amer. chem. Soc. 67, 1524.

Dunn, M. S., Camien, M. N., Shankman, S. \& Block, H. (1947). F. biol. Chem. I68, 43.

Greene, R. D. \& Black, A. (1944). Y. biol. Chem. 155, 1.

Heathcote, J. G. (1948). Biochem. F. 42, 305.

Heathcote, J. G. (1949). F. gen. Microbiol. 3, 392.

Henderson, L. M. \& Snell, E. E. (1948). \%. biol. Chem. 172, 15.

Jones, D. B. (1926). Cer. Chem. 3, I94.

Jones, D. B. (1931). Circ. U.S. Dep. Agric. no. 183.

Jones, D. B. \& Gersdorff, C. E. F. (1925). F. biol. Chem. 64, 241.

Lyman, C. M., Moseley, O., Wood, S. \& Hale, F. (1946). Arch. Biochem. 10, 427.

Martin, A. J. P. \& Synge, R. L. M. (1945). Adv. Protein Chem. 2, I. 
McElroy, L. W., Clandinin, D. R., Lobay, W. \& Pethybridge, S. I. (1949). F. Nutrit. 37, 329.

Morrison, F. B. (1947). Feeds and Feeding, 2oth ed. New York: The Morrison Publishing Co.

Osborne, T. B. (1924). The Vegetable Proteins, 2nd ed., p. ro. New York: Longmans, Green and Co.

Osborne, T. B. \& Voorhees, C. G. (1893). Amer. chem. Y. 15, 392.

Rees, .M. W. (1946). Biochem. Y. 40, 632.

Richardson, C. (1886). Bull. U.S. Bur. Chem. no. 9.

Sauberlich, H. F. \& Baumann, C. A. (1949). F. biol. Chem. 177, 545.

Snell, E. E. (1945). Adv. Protein Chem. 2, 99.

Stokes, J. L., Gunness, M., Dwyer, I. M. \& Caswell, M. C. (1945). F. biol. Chem. 160, 35.

Teller, G. I. (1896). Bull. Ark. agric. Exp. Sta. no. 42, Parts 1 and 2.

Teller, G. L. (1932). Cereal Chem. 9, 261.

Tristram, G. R. (1939). Biochem. F. 33, 1271.

Van Slyke, D. D., Hiller, A., Dillon, R. T. \& MacFadyen, D. (1938). Proc. Soc. exp. Biol., N.Y., 38,548 .

\title{
Changes Occurring in the Proteins as a Result of Processing Groundnuts under Selected Industrial Conditions.
}

\section{Physical and Chemical Changes}

\author{
BY J. W. LORD AND J. A. WAKELAM \\ Research Department, $\mathcal{F}$. Bibby and Sons Ltd., Liverpool
}

(Received 6 March I950)

Considerable quantities of groundnuts are being processed in oil-mills in this country and it is reasonable to suppose that the amount will increase in the future. The high oil content $(44-50 \%)$ of the decorticated seed makes groundnuts more difficult to process than most high-protein seeds. In particular, the oil is not so easily extracted as from soya and cottonseed (oil content about $20 \%$ ). Much work has been done on cottonseed and soya beans in the United States, where they are major crops. Little work has so far been published on groundnuts in America, and attention in this country has largely concentrated on maximal oil extraction. The very serious shortage of animal protein available for non-human consumption enhances, however, the importance of vegetable sources of protein and makes it essential that wastage or damage of such protein shall be avoided wherever possible.

The present investigation was carried out using industrial plant under selected conditions considered commercially feasible, and it is essentially a study of the effects of temperature and humidity on the protein. As a background to this work, a brief outline of typical oil-mill practice may be relevant.

The groundnut seeds are usually received in a decorticated state, and it was on material of this type that the present work was done. The raw material is first subjected in steam-heated pots to a slight cooking process lasting $15^{-20} \mathrm{~min}$. at a temperature of 90-100 using dry heat. The object of this is to give the nuts mechanical strength for the subsequent treatment which consists of screw-pressing in 'expeller' machines. 'These machines consist essentially of a conical steel shaft set with its axis horizontal and bearing a raised steel thread which turns in a conical steel housing. The material, introduced at the base of the cone, is 'wormed' toward the apex and crushed between 